\title{
Polyethylene Mulch Modifies Greenhouse Microclimate and Reduces Infection of Phytophthora infestans in Tomato and Pseudoperonospora cubensis in Cucumber
}

\author{
D. Shtienberg, Y. Elad, M. Bornstein, G. Ziv, A. Grava, and S. Cohen
}

First, second, and third authors: Department of Plant Pathology and Weed Research, Institute of Plant Protection, ARO, the Volcani Center, P.O. Box 6 Bet Dagan, Israel; fourth, fifth, and sixth authors: Department of Environmental Physics and Irrigation, Institute of Soil, Water and Environmental Science, ARO, the Volcani Center, P.O. Box 6, Bet Dagan 50250, Israel.

Accepted for publication 20 August 2009.

\begin{abstract}
Shtienberg, D., Elad, Y., Bornstein, M., Ziv, G., Grava, A., and Cohen, S. 2010. Polyethylene mulch modifies greenhouse microclimate and reduces infection of Phytophthora infestans in tomato and Pseudoperonospora cubensis in cucumber. Phytopathology 100:97-104.

The individual and joint effects of covering the soil with polyethylene mulch before planting and fungicides commonly used by organic growers on tomato late blight (caused by Phytophthora infestans) were studied in three experiments conducted from 2002 to 2005. Application of fungicides resulted in inconsistent and insufficient late blight suppression (control efficacy \pm standard error of $34.5 \pm 14.3 \%$ ) but the polyethylene mulch resulted in consistent, effective, and highly significant suppression (control efficacy of $83.6 \pm 5.5 \%$ ) of the disease. The combined effect of the two measures was additive. In a second set of three experiments

carried out between 2004 and 2006, it was found that the type of polyethylene mulch used (bicolor aluminized, clear, or black) did not affect the efficacy of late blight suppression (control efficacy of 60.1 to $95.8 \%$ ) and the differences in the effects among the different polyethylene mulches used were insignificant. Next, the ability of the mulch to suppress cucumber downy mildew (caused by Pseudoperonospora cubensis) was studied in four experiments carried out between 2006 and 2008. The mulch effectively suppressed cucumber downy mildew but the effect was less substantial (control efficacy of $34.9 \pm 4.8 \%$ ) than that achieved for tomato late blight. The disease-suppressing effect of mulch appeared to come from a reduction in leaf wetness duration, because mulching led to reductions in both the frequency of nights when dew formed and the number of dew hours per night when it formed. Mulching also reduced relative humidity in the canopy, which may have reduced sporulation.
\end{abstract}

Tomato and cucumber are grown in the Mediterranean Basin, including Israel, in low-cost greenhouse production systems. Seedlings are planted directly in the soil and irrigated by dripirrigation systems. The greenhouses are covered with infrared (IR)-obstructing antidrop polyethylene sheets but are not heated or force ventilated. Side vents are opened on rainless days to enhance air exchange and reduce relative humidity $(\mathrm{RH})$ in the greenhouses (28). Nevertheless, due to the limited ability to manipulate environmental conditions within the greenhouse, plants are often exposed to significant fluctuations in temperature and $\mathrm{RH}$ and to prolonged periods of leaf wetness $(2,18)$. These conditions are conducive to several plants pathogens, among them Phytophthora infestans (Mont.) de Bary, and Pseudoperonospora cubensis (Berk. \& M. A. Curtis) Rostovzev, the causal agents of tomato late blight and cucumber downy mildew, respectively. Both pathogens are common in all Mediterranean countries and are well known for their explosive development when environmental conditions are suitable and host plants are susceptible to infection $(23,24,29)$.

Management of tomato late blight and cucumber downy mildew is a challenge in conventional farming, and growers rely mainly on chemical control. In organic farming, coping with these diseases is much more problematic because the only permitted chemical is copper. Copper, in the form of copper hydroxide, copper oxychloride, copper sulfate, and cuprous oxide, must be

Corresponding author: D. Shtienberg; E-mail address: danish@ volcani.agri.gov.il

doi:10.1094/PHYTO-100-1-0097

This article is in the public domain and not copyrightable. It may be freely reprinted with customary crediting of the source. The American Phytopathological Society, 2010 applied as a prophylactic fungicide, because it is not systemic and may only prevent the new infections (23). The use of copper may have long-term consequences due to its accumulation in the soil (11); thus, it appears to be incompatible with organic farming's objectives of sustainability and environmentally friendly farming. Therefore, the use of copper was restricted by the EU Commission (Regulation EC no. 437/2002), which set a quantitative ceiling of $6 \mathrm{~kg}$ of copper per hectare per year (15). As soon as reliable alternatives to late blight management are available, a complete ban on copper compounds should take place (10). Thus, there is enormous interest in finding effective, nonchemical alternatives to protect organic crops against their most threatening foliar diseases.

Disease outbreak depends mainly on inoculum availability, temperature, high RH, and leaf wetness duration. Nevertheless, the limiting factor in every epidemiological consideration of these pathogens is leaf wetness. Unless free moisture is available on the leaf surface for germination of sporangia and zoospores and the penetration of germ tubes into the host, and high RH prevails for sporulation, all other factors become irrelevant $(3,7,8,14,24,31)$. Because moisture is required for infection and high $\mathrm{RH}$ is necessary for sporulation, prevention of these conditions largely precludes development of the diseases under conditions that lead to severe epidemics. The problem is how to prevent periods with high RH and leaf wetness (or at least reduce their duration) in low-cost greenhouse production systems. This study shows that one of the measures that can be used is polyethylene mulch. Reducing air humidity by mulching has been suggested as a means to restrict the humidity-promoted gray mold disease (Botrytis cinerea) development $(12,13)$. Nevertheless, implementation of polyethylene mulching as a mean to manage foliar 
diseases in general, and downy mildew and late blight in particular, was not studied in greenhouse production.

Polyethylene mulches are used mainly in outdoor production. This technology is used in chemical (25) and solar (19) soil disinfection, for weed control (16), and to protect crops from virus infestation vectored by insect pests (1). Polyethylene mulch alters the environmental conditions in the soil and also alters the environmental conditions in the atmosphere above the mulch (30). The actual effects and their magnitude depend, among other things, on the characteristics of the polyethylene sheet used (e.g., chemical composition, color, thickness, and reflectance properties) and how the covering was performed (e.g., attached to the soil or not). Our working hypothesis was that mulching with polyethylene before planting would alter the microclimate within the canopy in a way that the conditions would be less favorable to disease development. The initial aim was to develop means to adequately cope with late blight management in organic tomato production with reduced rates of copper. Based on the findings of the initial set of experiments (conducted in autumn 2002-03 to 2004-05), the study was extended and new objectives were designated. We examined whether the type of polyethylene used affected disease suppression and whether the polyethylene mulch was also effective against cucumber downy mildew. The physical mechanism by which mulching alters the microclimatic conditions will not be elaborated in this report. Preliminary results have been published elsewhere (6).

\section{MATERIALS AND METHODS}

Cultural practices. The experiments were carried out in the Be'sor Experimental Station $\left(31^{\circ} 16^{\prime} \mathrm{N}, 34^{\circ} 24^{\prime} \mathrm{E}\right.$; $75 \mathrm{~m}$ above sea level) in the Northern Negev, Israel, in walk-in tunnels and greenhouses. The walk-in tunnels were $6 \mathrm{~m}$ long, $6.3 \mathrm{~m}$ wide, and $2.5 \mathrm{~m}$ high $\left(37.8 \mathrm{~m}^{2}\right)$. The greenhouses were $20 \mathrm{~m}$ long, $12 \mathrm{~m}$ wide, and $6.6 \mathrm{~m}$ high $\left(240 \mathrm{~m}^{2}\right)$. The walk-in tunnels and greenhouses were covered with clear IR-type polyethylene sheets and were not heated or actively ventilated. The two ends of the walkin tunnels were covered with 50-mesh polyethylene screens. The greenhouses had side vents that were opened for 5 to $8 \mathrm{~h}$ daily on rainless days and the openings were covered with 50-mesh screen material. Tomato (Lycopersicon esculentum; cvs. 496 and 1402) and cucumber (Cucumis sativus; cvs. IV36, Sokrates, and Mukhasen) seedlings were planted in the soil on the dates specified below. Both tomato cultivars were susceptible to Phytophthora infestans and the cucumber cultivars were susceptible to Pseudoperonospora cubensis. Tomato plants were grown in beds of two rows each. Plants were spaced $0.5 \mathrm{~m}$ apart within rows; the distance between rows in each bed was $0.4 \mathrm{~m}$ and the distance between beds was $1.5 \mathrm{~m}$. Cucumber plants were grown in single rows; plants were spaced $0.5 \mathrm{~m}$ apart within rows and the distance between beds was $1.6 \mathrm{~m}$. Plants were grown in a high-wire trellis cropping system and maintained according to the recommendations of the extension service in the region. No fungicides for the control of late blight (in the tomato experiments) and downy mildew (in the cucumber experiments) were applied except those outlined in the experimental design below.

Experimental design. The first set of the experiments aimed at quantifying the joint effects of chemical control and soil-covering on tomato late blight under organic farming. Three experiments were carried out in the autumn seasons of 2002-03, 2003-04, and 2004-05. Seedlings were planted in 27 October 2002, 21 September 2003, and 28 September 2004 for the corresponding seasons. The experiments were laid out in a split-plot design with two factors. The first factor, mulching (in the main plots), comprised two levels: the soil was either not covered or covered before planting with bicolor aluminized polyethylene mulch (silver-gray on the upper side and black on the lower side) produced by Ginegar Plastic Products Ltd. (Kibbutz Ginegar,
Israel). All the walk-in tunnel soil (including the paths between the beds) was mulched. Holes (5 to $10 \mathrm{~cm}$ in diameter) were cut manually with razor knives and seedlings were planted within these holes. The mulch remained in place throughout the entire season. The second factor, chemical control (in the subplots, randomized within the main plots), was applied at three (in 200203) or five (in 2003-04 and 2004-05) levels: the plants were not sprayed with fungicides against late blight or they were sprayed weekly with fungicides permitted in organic tomato production. Results reported here are from the common management practice treatment (Kocide 2000 plus Neemguard). Each treatment combination was replicated four to five times. The main experimental plots were walk-in tunnels (in autumn 2002-03) or commerciallike greenhouses (in autumn 2003-04 and 2004-05). Each secondary plot was one bed, $5 \mathrm{~m}$ in length in the 2002-03 experiment and $20 \mathrm{~m}$ in length in the 2003-04 and 2004-05 experiments. Copper hydroxide (Kocide 2000, 53.8\% a.i. WG, DuPont, USA) at a rate of $0.5 \%$ plus Neem oil (Neemguard, 95\% a.i.; Certis USA, USA) at a rate of $2 \%$ were applied with a backpack sprayer adjusted to $0.5 \mathrm{MPa}$ of pressure or by a gun sprayer. Care was taken to avoid drift to adjacent plots. Spray volume was calibrated to 500 to 1,000 liters of water per hectare according to the height of the plants. Spraying was initiated 4 to 5 weeks after planting, before initial late blight symptoms were observed in the experimental plots, and continued at 5- to 8-day intervals until the end of the experiments. In all, 9 sprays were applied in the autumn 2002-03 experiment, 15 in the 2003-04 experiment, and 16 in the 2004-05 experiment.

The second set of experiments aimed at determining whether the type of polyethylene mulch affected disease suppression. Three experiments were performed in autumn 2004-05 and 2005-06 and in spring 2006. Tomato seedlings were planted in the walk-in tunnels on 15 October 2004, 15 September 2005, and 18 February 2006 for the corresponding seasons. The experiments were laid out in a randomized block design with four replicates of four treatments: (i) noncovered soil, (ii) bicolor aluminized polyethylene mulch, (iii) clear polyethylene mulch, and (iv) black polyethylene mulch.

The third set of experiments aimed at determining whether mulching was also effective against cucumber downy mildew. Four experiments were performed in autumn 2006-07, winter 2006-07, autumn 2007-08, and spring 2008. Cucumber seedlings were planted in the walk-in tunnels on 21 September 2006, 19 November 2006, 16 October 2007, and 23 January 2008 for the corresponding seasons. The experiments were laid out in a randomized block design with four replicates and two treatments: noncovered soil or clear polyethylene mulch.

Measurement of microclimate. In the 2002-03 to 2004-05 and 2006-07 to 2008 experiments, temperature and $\mathrm{RH}$ were measured hourly with dataloggers (HOBO Pro-series Ltd., Contoocook, $\mathrm{NH}$ ) installed $1 \mathrm{~m}$ above the ground within the plant canopy. At least two loggers were placed within each treatment; recorded data (for each treatment) were averaged before analysis. Data were used to calculate the daily minimum, maximum, and average temperatures and $\mathrm{RH}$; the number of hours with $\mathrm{RH}>$ $90 \%$; and the average temperature at times with $\mathrm{RH}>90 \%$.

In the 2005 and 2006 experiments, wet- and dry-bulb thermocouple temperatures were measured at a height of $2 \mathrm{~m}$ with aspirated psychrometers monitored by a datalogger system (CR10X and AM416 multiplexer; Campbell Scientific, Logan, UT) (6). Relative humidity was computed from the psychrometric equation. In our study, we did not measure leaf wetness but, instead, calculated the dew-point temperature and assumed that the leaves were wet at times when the difference between air temperature and dew-point temperature was $\leq 0.2^{\circ} \mathrm{C}$ (the sensors' measurement error).

Disease assessment and data analyses. Natural epidemics of Phytophthora infestans developed in five of the six tomato ex- 
periments and natural epidemics of Pseudoperonospora cubensis developed in all cucumber experiments. In autumn 2005-06, late blight symptoms were not observed until mid-November 2005. On 17 November, plants in the corners of the outer rows in each walk-in tunnel were sprayed with a suspension of Phytophthora infestans sporangia $\left(5 \times 10^{4}\right.$ sporangia/ml). Inoculation was performed just before sunset, so that the wetness provided by inoculation would persist until the next morning. These artificially inoculated plants served as the source of inoculum for the other plants in each tunnel. Disease assessments were performed only on plants in the inner beds in each tunnel, which were infected naturally.

Disease severity (the percentage of the foliage exhibiting disease symptoms) was assessed visually on beds in the center of each experimental plot. In autumn 2002-03, disease severity was assessed once, at the end of the season (2 May 2003). In all other experiments, disease severity was recorded periodically, commencing soon after disease onset and continuing at 7- to 14-day intervals until the end of the experiments. The area under the disease progress curve (AUDPC) was calculated on the basis of the season-long disease assessments. To compare AUDPC values from different experiments, the relative AUDPC (RAUDPC) was calculated by dividing the AUDPC by the duration of the epidemic. RAUDPC units are percentages. The disease severity or RAUDPC values recorded in treated $\left(D_{t}\right)$ and in reference $\left(D_{r}\right)$ treatments were used to calculate the control efficacy (CE;\%) according to the formula $\left(D_{r}-D_{t}\right) / D_{r} \times 100$.

The joint effect of the control measures used was estimated by means of the Abbott formula (20,21). The expected disease CE and the joint suppression action were calculated as $\mathrm{CE}_{\text {exp }}=a+$ $b-a \times b / 100$ and synergy factor $(\mathrm{SF})=\mathrm{CE}_{\text {obs }} / \mathrm{CE}_{\mathrm{exp}}$, where $a=$ $\mathrm{CE}$ of one measure when applied alone, $b=\mathrm{CE}$ of the other measure when applied alone, $\mathrm{CE}_{\exp }=$ expected $\mathrm{CE}$ of the integration if the two measures act additively, $\mathrm{CE}_{\mathrm{obs}}=$ observed $\mathrm{CE}$ of the integration, and $\mathrm{SF}=$ the SF achieved by the integration. When $\mathrm{SF}=1$, the interaction between the control measures is additive; when $\mathrm{SF}<1$, the interaction is antagonistic; and when SF $>1$, the interaction is synergistic $(20,21)$. In quantifying the joint action of soil covering and chemical control, the RAUDPC values recorded in unsprayed plants growing in noncovered soil was used as the reference. The contribution of chemical control was estimated by comparing RAUDPC values recorded in fungicide-sprayed plants; that of soil-covering was estimated by comparing the RAUDPC values recorded in unsprayed plants growing in mulched plots. RAUDPC records from fungicide-sprayed plants growing in mulch treatments were used to estimate the joint contribution of mulching and chemical control.

Statistical analysis. Data from the replicated plots were analyzed with Student's $t$ test, analysis of variance (ANOVA), or regression analyses, as appropriate. When the $F$ statistic of ANOVA was significant at $P \leq 0.05$, significance of the differences were determined according to the Tukey-Kramer honestly significant difference test at $P=0.05$. Statistical analyses of the data were performed using JMP-in software (version 5; SAS Institute Inc., Cary, NC).

\section{RESULTS}

Effects of polyethylene mulch on disease severity. The individual and joint effects of mulching and chemical control on tomato late blight were first examined in autumn 2002-03 in walk-in tunnels. The natural late blight infections resulted in moderate disease severity $(37.5 \%)$ by the end of the experiment in nonmulched, untreated plots. Bicolor polyethylene mulch before planting and weekly Kocide 2000 plus Neemguard sprays each reduced disease severity. ANOVA revealed that the interaction between these two measures was insignificant $(P=0.134)$ but the effect of each of the measures was highly significant (for mulch- ing, $P=0.0007$, and for fungicide spraying, $P=0.02)$. The sole effect of mulching in suppression of late blight $(\mathrm{CE}=83.5 \%)$ was significantly larger than the sole effect of spraying $(\mathrm{CE}=56.9 \%)$. The combined effect was additive $(\mathrm{SF}=1.03)$ and reduced disease severity by $96.0 \%$ (Fig. 1). To test whether the effect of mulching on the disease was related to the relatively small size of the walk-in tunnels ( $37.8 \mathrm{~m}^{2}$ each), two experiments were carried out in the following seasons in greenhouses $\left(240 \mathrm{~m}^{2}\right.$ each). The late blight epidemics that developed in the control (nonmulched) plots in these experiments resulted in nearly complete destruction of the plants and, by the end of the season, disease severity was 92.5 and $81 \%$ in the 2003-04 and 2004-05, respectively. Weekly application of fungicides permitted in organic farming had no significant effect $(P=0.05)$ on disease severity throughout the season or on the RAUDPC values. However, the bicolor polyethylene mulch reduced disease severity and RAUDPC significantly. The effect was more pronounced in the 2003-04 experiment, where final disease severity in unsprayed plots in mulched greenhouses was $14.4 \%$, compared with $40.1 \%$ in the $2004-05$ experiment. The interaction between mulching and spraying was insignificant (Fig. 2; Table 1). SFs (1.03 and 1.10, respectively) suggest additive effects, because the SF values did not differ significantly from 1 (one-tailed $t$ test).

In the experiments from 2002-03 to 2004-05 presented above, bicolor aluminized polyethylene was used for mulching. Subsequently, other types of polyethylene were examined in three experiments. Severe late blight epidemics developed in plants growing in nonmulched soil: final disease severity was 85.0, 48.5, and $80.0 \%$ in the autumn 2004-05 and 2005-06 and spring 2006 experiments, respectively. Disease severity and RAUDPC values were significantly lower in all tunnels with polyethylene mulch (CE values of 60.1 to $95.8 \%$ ) and the differences in the effects among the polyethylene types were insignificant (Fig. 3; Table 2).

The possibility of using polyethylene mulch for suppression of cucumber downy mildew was examined in four experiments conducted from autumn 2006-07 to spring 2008. Severe downy mildew epidemics developed in all experiments, with final disease severity ranging from $55.1 \%$ in the autumn 2006-07 experiment to $90.6 \%$ in the autumn $2007-08$ experiment. Downy mildew severity was reduced significantly by mulching in three of the four experiments but the effects were less pronounced than those observed in the tomato late blight experiments. CE values (based on RAUDPC measures) were 7.7 to $44.8 \%$ (Fig. 4; Table 3 ).

Effects of polyethylene mulch on microclimate. Effects of mulching on RH and temperature were recorded in the 2002-03

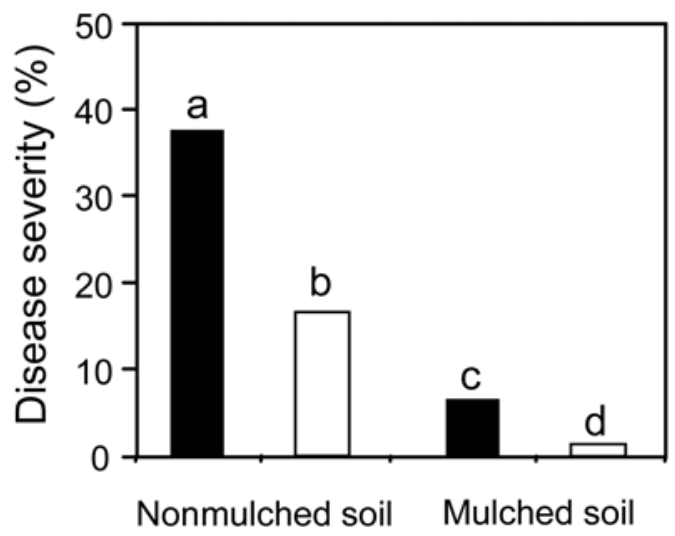

Fig. 1. Effects of mulching and chemical control on tomato late blight development in walk-in tunnels in autumn 2002-03. The soil was mulched or not with bicolor aluminized polyethylene before planting. Plants were left untreated (filled bars) or sprayed with a mixture of Kocide $2000(0.5 \%)$ and Neemguard (2\%) in weekly intervals (open bars). Disease severity was recorded on 2 March 2003. Bars accompanied by different letters differ significantly as determined by the highly significant difference test at $P=0.05$. 
to 2004-05 tomato experiments and 2006-07 to 2008 cucumber experiments. Results of three tomato experiments are presented here as an example. Comparison of air temperature recorded hourly within the plant canopy in mulched versus nonmulched tunnels and greenhouses revealed up to $2.4^{\circ} \mathrm{C}$ differences. However, the magnitude of these differences and their diurnal timing fluctuated with no clear pattern (data not shown). Effects on RH were more consistent (i.e., RH was usually lower in mulch treatments) but varied over time and between experiments. In December 2002 and 2003, at the time of late blight onset in the corresponding 2002-03, 2003-04, and 2003-04 experiments, the number of hours with $\mathrm{RH}>90 \%$ was markedly larger in
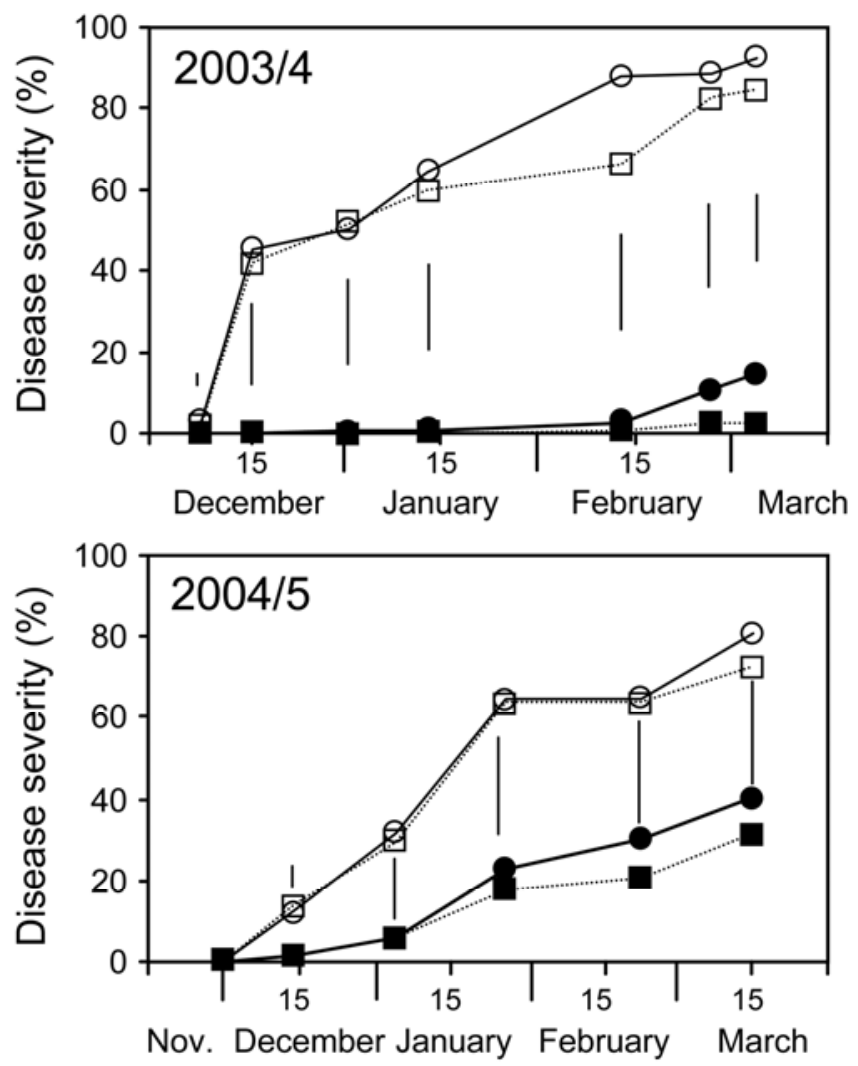

Fig. 2. Effects of mulching and chemical control on tomato late blight development in two greenhouse experiments. Open symbols $=$ nonmulched soil and filled symbols $=$ bicolor aluminized polyethylene mulch before planting. Circles $($ solid line $)=$ untreated and squares $($ dotted line $)=$ plants were sprayed weekly with a mixture of Kocide $2000(0.5 \%)$ and Neemguard $(2 \%)$. Bars represent the least significant difference for each sampling date, as determined by the highly significant difference test at $P=0.05$.

TABLE 1. Effects of mulching and chemical control on the relative area under the late blight progress curve (RAUDPC) in two tomato experiments conducted in greenhouses ${ }^{\mathrm{y}}$

\begin{tabular}{lcc}
\hline & \multicolumn{2}{c}{ RAUDPC (\%) } \\
\cline { 2 - 3 } Mulch, treatment ${ }^{\mathrm{z}}$ & Autumn 2003-04 & Autumn 2004-05 \\
\hline Nonmulched & $68.5 \mathrm{a}$ & $43.9 \mathrm{a}$ \\
Untreated & $60.2 \mathrm{a}$ & $42.9 \mathrm{a}$ \\
Kocide & & \\
Mulched & $2.8 \mathrm{~b}$ & $14.7 \mathrm{~b}$ \\
Untreated & $0.6 \mathrm{~b}$ & $11.3 \mathrm{~b}$ \\
Kocide &
\end{tabular}

${ }^{\mathrm{y}}$ Disease progress curves are presented in Figure 2. In each column, numbers with different letters differ significantly as determined from the highly significant difference test at $P=0.05$.

${ }^{\mathrm{z}}$ Soil mulching and fungicide treatment. Mulched $=$ bicolor aluminized polyethylene mulch before planting and Kocide = plants sprayed weekly with a mixture of Kocide $2000(0.5 \%)$ plus Neemguard (2\%). nonmulched compared with mulched greenhouses. For example, $12 \mathrm{~h} /$ day with $\mathrm{RH}>90 \%$ in the nonmulched greenhouses corresponded to $5.2 \mathrm{~h} /$ day in the 2002-03 experiment and $6.1 \mathrm{~h} /$ day in the 2003-04 experiment in the mulched greenhouses (Fig. 5A and C). Although disease severity increased gradually until the end of the season, small, insignificant differences in the number of hours with $\mathrm{RH}>90 \%$ were observed between the treatments in February of 2003 and 2004 (Fig. 5B and D). Results in the 2004-05 experiments were different; no effects on RH were observed in December 2004 but, in February 2005, 12 h/day with RH > 90\% in the nonmulch treatment corresponded to $8.3 \mathrm{~h} /$ day in the mulch treatment (Fig. 5E and F).
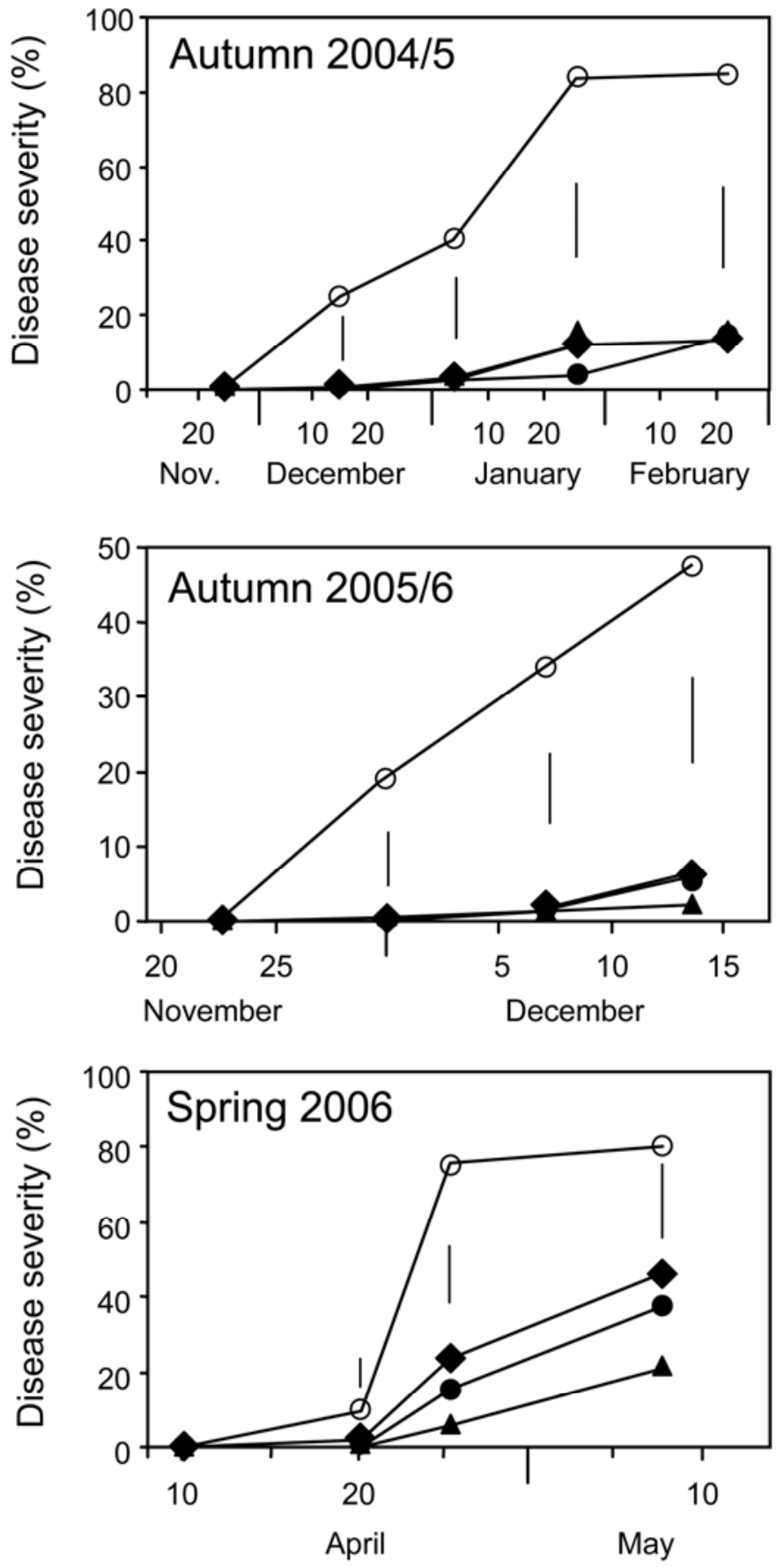

Fig. 3. Effect of type of polyethylene mulch on tomato late blight development in three experiments in walk-in tunnels. Open circles, nonmulched; filled symbols, bicolor aluminized (circles), clear (triangles), or black (diamonds) polyethylene mulch. Plants were not sprayed with any fungicide. Bars represent the least significant difference for each sampling date as determined by the highly significant difference test at $P=0.05$. 
Effects of mulching and mulch type on dew formation were determined for the autumn 2004-05 and 2005-06 and spring 2006 experiments. In this report, results for the spring 2006 experiment are presented. Dew was formed only at night, commencing at $2200 \mathrm{~h}$ (on average) and lasting up to $0530 \mathrm{~h}$. The earliest record of dew formation was $1900 \mathrm{~h}$ and the latest time at which dew was still apparent was $0800 \mathrm{~h}(\approx 2 \mathrm{~h}$ after sunset and sunrise, respectively). On $54 \%$ of the nights, dew was not formed and the leaves remain dry all night long; on $38 \%$ of the nights, dew formed in nonmulched tunnels but, in the tunnels with bicolor or clear polyethylene mulches, leaves remained dry; and, on $8 \%$ of the nights, dew was formed in all tunnels (Figs. 6 and 7A). On nights with dew, the average duration of dew in the nonmulched tunnels was $6 \mathrm{~h} 15 \mathrm{~min}$; in the tunnels with bicolor or clear polyethylene mulches, the duration of dew was $2 \mathrm{~h} 15 \mathrm{~min}$ and $1 \mathrm{~h}$ 45 min (on average), respectively (Fig. 7B).

TABLE 2. Effect of the type of polyethylene mulch on the relative area under the late blight progress curve (RAUDPC) in three tomato experiments conducted in walk-in tunnels ${ }^{y}$

\begin{tabular}{lccc}
\hline & \multicolumn{3}{c}{ RAUDPC (\%) } \\
\cline { 2 - 4 } Polyethylene $^{z}$ & Autumn 2004-05 & Autumn 2005-06 & Spring 2006 \\
\hline Nonmulched & $50.6 \mathrm{a}$ & $14.5 \mathrm{a}$ & $45.8 \mathrm{a}$ \\
Bicolor aluminized & $3.8 \mathrm{~b}$ & $0.6 \mathrm{~b}$ & $14.8 \mathrm{~b}$ \\
Black & $6.1 \mathrm{~b}$ & $0.7 \mathrm{~b}$ & $18.3 \mathrm{~b}$ \\
Clear & $6.5 \mathrm{~b}$ & $1.2 \mathrm{~b}$ & $17.1 \mathrm{~b}$ \\
\hline
\end{tabular}

${ }^{y}$ Disease progress curves are presented in Figure 4. In each column, numbers with different letters differ significantly as determined according to the highly significant difference test at $P=0.05$.

${ }^{\mathrm{z}}$ Polyethylene type used for soil mulching; mulch applied before planting.

\section{DISCUSSION}

The initial aim of the current study was to develop means to adequately cope with late blight management in organic tomato farming with reduced rates of copper application. Application of fungicides commonly used by organic growers resulted in inconsistent and insufficient late blight suppression (CE \pm standard error [SE] of $34.5 \pm 14.3 \%$ ) in the 2002-03 to 2004-05 experiments (Figs. 1 and 2; Table 1). The reasons for the low efficacy of spraying in our experiments are not fully understood; however, we note that organic growers also often fail to manage late blight in commercial production systems. In contrast to chemical control, polyethylene mulch resulted in consistent, effective, and highly significant suppression of late blight $(\mathrm{CE} \pm \mathrm{SE}$ of $83.6 \pm$ $5.5 \%$ ). The combined effect of fungicide and mulching was additive in the three experiments where both measures were tested;

TABLE 3. Effect of mulching on the relative area under the downy mildew progress curve (RAUDPC) in four cucumber experiments conducted in walkin tunnels ${ }^{\mathrm{y}}$

\begin{tabular}{lcccc}
\hline & \multicolumn{4}{c}{ RAUDPC (\%) } \\
\cline { 2 - 5 } Mulch $^{\mathrm{z}}$ & Autumn & Winter & Autumn & Spring \\
\hline Nonmulched & $2006-07$ & $2006-07$ & $2007-08$ & 2008 \\
Mulched & $24.0 \mathrm{a}$ & $27.3 \mathrm{a}$ & $46.8 \mathrm{a}$ & $22.1 \mathrm{a}$ \\
\hline
\end{tabular}

${ }^{y}$ Disease progress curves are presented in Figure 7. In each column, numbers with different letters differ significantly as determined from the highly significant difference test at $P=0.05$.

${ }^{\mathrm{z}}$ Mulch $=$ clear polyethylene mulch before planting.
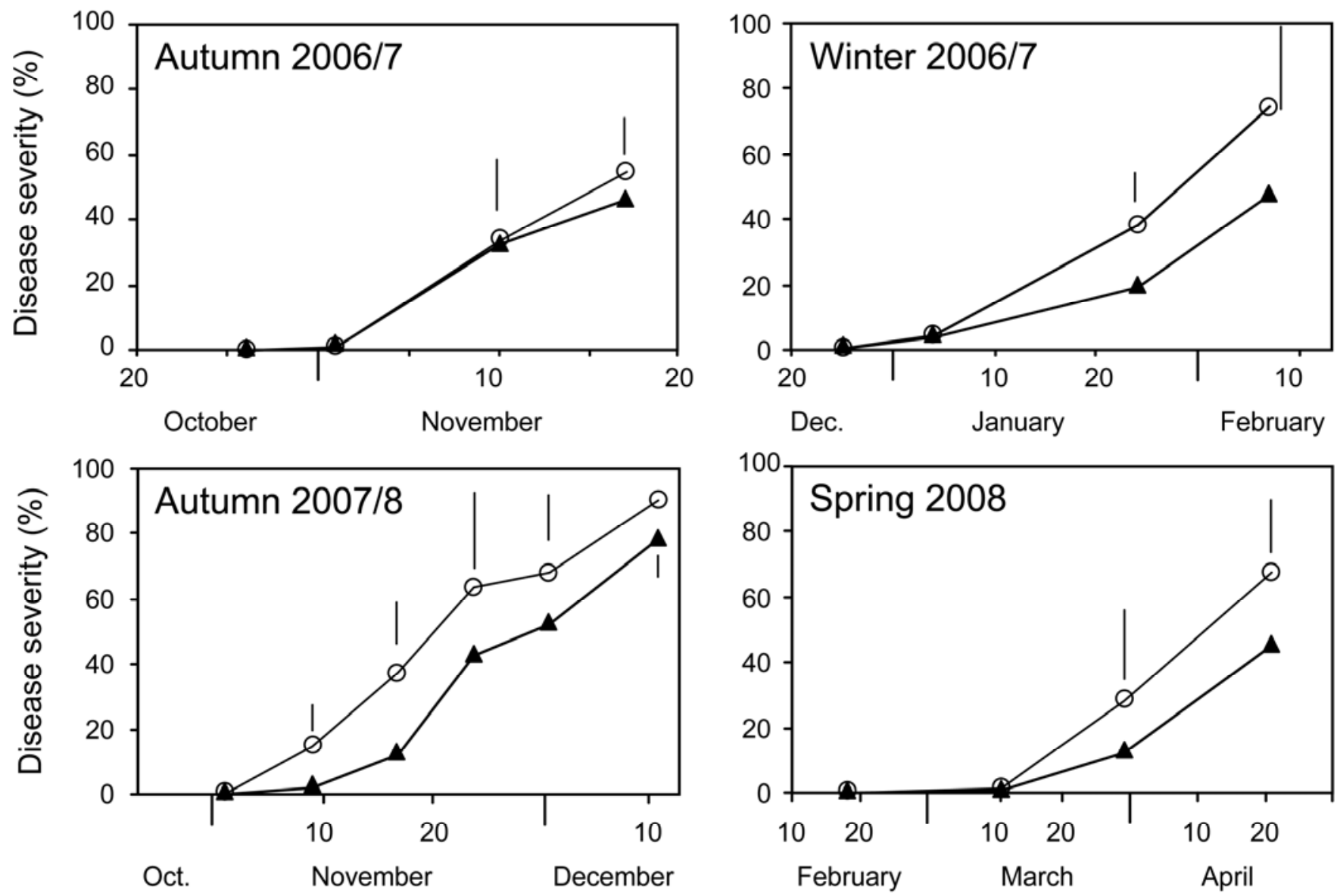

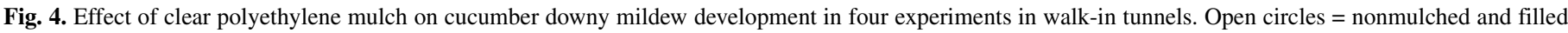

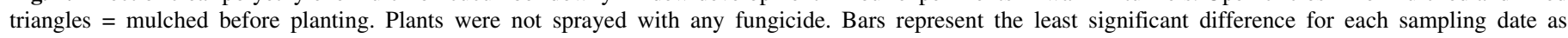
determined by the highly significant difference test at $P=0.05$. 
thus, application of both measures may enable improved late blight suppression (Figs. 1 and 2; Table 1).

The high efficacy of mulching was not expected. In fact, in all three experiments where both measures were jointly implemented, the efficacy of mulching greatly (and significantly) exceeded that of chemical control. In a second set of experiments, it was found that the type of polyethylene mulch used did not affect the efficacy of disease suppression (Fig. 3). Next, the ability to manage Pseudoperonospora cubensis was examined. Polyethylene mulch effectively suppressed cucumber downy mildew but the effect was less substantial: $\mathrm{CE} \pm \mathrm{SE}$ was $34.9 \pm 4.8 \%$ (Fig. 4; Table 3). These findings raised several questions. What was the biological mechanism by which polyethylene mulch suppressed late blight so effectively? What was the physical mechanism? Why were the effects on Phytophthora infestans greater than on Pseudoperonospora cubensis? Will this technology be effective against other pathogens? In other crops? Below, we will deal with these questions.

Mills et al. (22) found that early blight (Alternaria solani) and Septoria leaf spot (Septoria lycopersici) in fresh market tomato crops were reduced in plots mulched with black polyethylene compared with bare soil. Reduction in foliar disease in mulched plots was associated with reduced splash dispersal of inoculum and, in one out of two trials, reduced leaf wetness. Strawberry plants grown in beds mulched with black polyethylene had lower incidences of $B$. cinerea-incited rot than those grown in beds mulched with either clear polyethylene or paddy straw (27). Reducing air humidity by mulching with polyethylene has also been suggested as a means for restricting gray mold development in greenhouse crops $(12,13)$ but was not examined experimentally until recently (10).
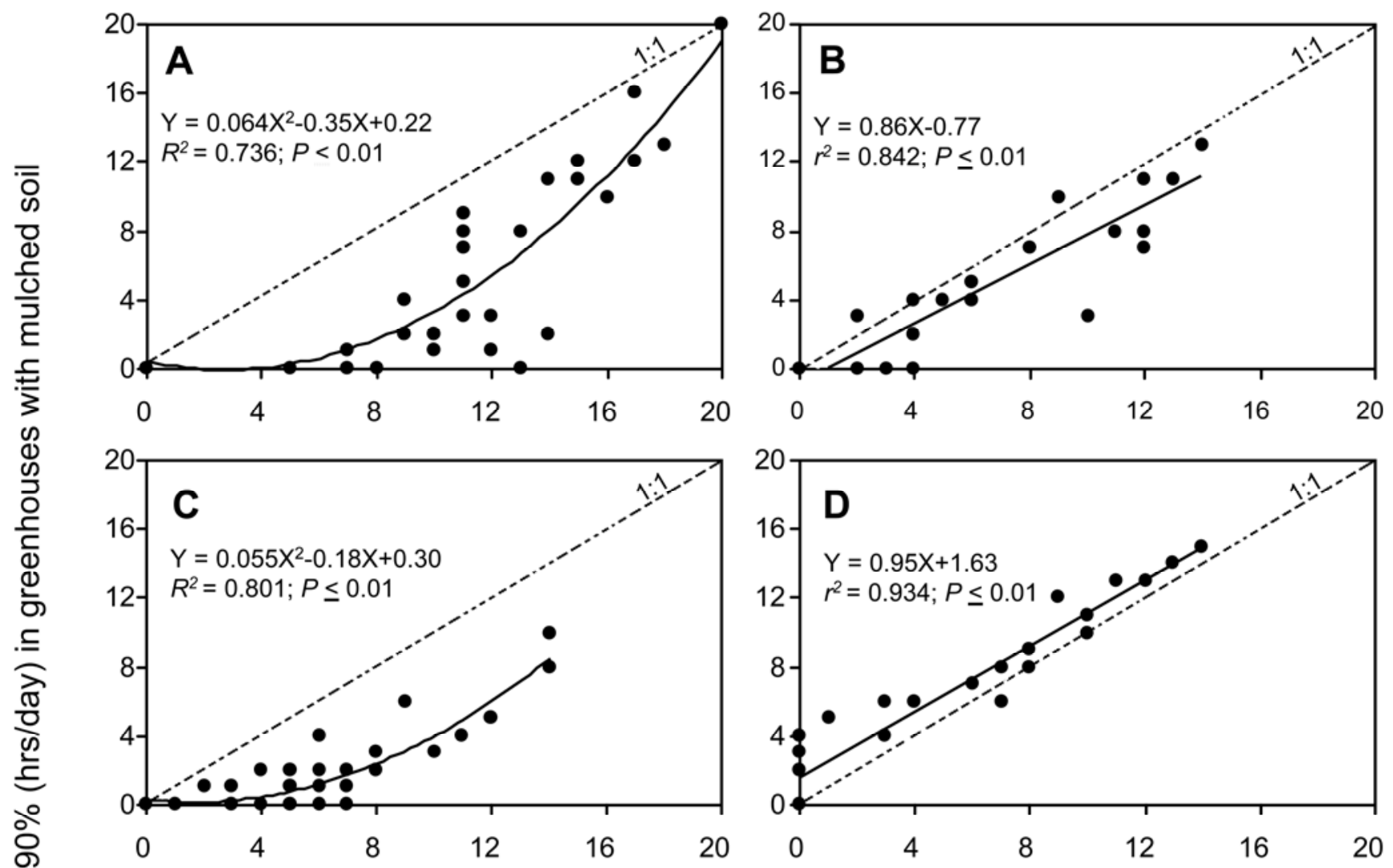

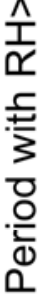
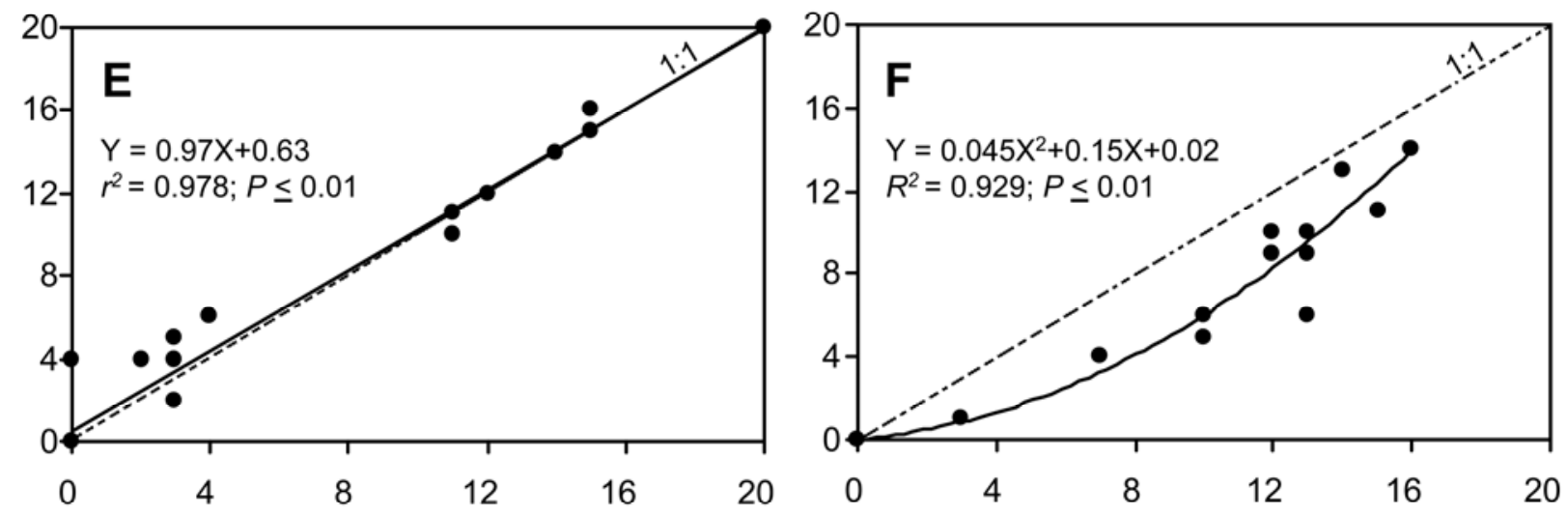

Period with $\mathrm{RH}>90 \%$ (hrs/day) in greenhouses with nonmulched soil

Fig. 5. Effect of bicolor aluminized polyethylene mulch on the daily period with relative humidity $(\mathrm{RH})>90 \%$ in three experiments. Tomato crops were planted $\mathbf{A}$ and B, in autumn 2002-03 in walk-in tunnels; and C and D, in 2003-04 and $\mathbf{E}$ and F, 2004-05 in greenhouses. Data were recorded in December A, 2002; C, 2003; and E, 2004 or in February B, 2003; D, 2004; and F, 2005. Unbroken lines were plotted based on the regression equations of the data; dotted 1:1 lines represent perfect coincidence between the two parameters. 
Cucumber downy mildew was less effectively suppressed by mulch than tomato late blight. For both Pseudoperonospora $\mathrm{cu}$ bensis and Phytophthora infestans, high RH and free moisture for a sufficient time are prerequisites for sporulation and infection. At optimal temperatures, both pathogens are capable of infecting their respective hosts within $2 \mathrm{~h}$ of leaf wetness. Nevertheless, at suboptimal temperatures Pseudoperonospora cubensis requires 2 to $4 \mathrm{~h}$ of wetness for infecting cucumber (8) whereas Phytophthora infestans requires $6 \mathrm{~h}$ or more of leaf wetness to infect tomato $(3,4,9,17)$. Consequently, it is possible that the observed differences in suppression of late blight and downy mildew epidemics caused by mulching resulted from the dissimilarity in $\mathrm{RH}$ and moisture requirements of the two pathogens. Another possibility is the differences in leaf shape, size, and architecture among the two host plants. Whereas tomato plants possess compound leaves and the area of individual leaflets is relatively small, leaves of cucumber plants are large. Perhaps the large lower leaves of cucumber plants blocked the heat flux from the soil and precluded the heating of upper leaves at night, resulting in cooling of the leaves and earlier formation and deposition of dew.

The biological mechanism by which mulching suppressed Phytophthora infestans and Pseudoperonospora cubensis is evident: mulching modified the environmental conditions within the canopy, reduced RH, and shortened leaf wetness duration. The reduced $\mathrm{RH}$ and leaf wetness duration presumably resulted in decreased sporulation, less sporangia germination, fewer infections, and a reduced amount of lesions; the outcome was less disease and milder epidemics. The physical mechanism by which mulching reduces RH and leaf wetness duration is not fully understood. Air temperature, $\mathrm{RH}$, and leaf temperature govern the formation and deposition of dew. As indicated above, mulching did not always affect air temperature significantly but additional measurements have shown that soil temperatures increased below the mulch. Soil covering reduced the duration of time with $\mathrm{RH}>90 \%$ in mulched structures compared with nonmulched structures, although the effects were not consistent in all experiments and did not persist for the entire season (Fig. 5). Thus, reduction of $\mathrm{RH}$ may only partially explain the biological effect of mulching.

Mulching affected dew-point temperature in such a way that dew formation was prevented or at least postponed: the number of dewy nights was reduced by $83 \%$ and the duration of dew deposition (in the dewy nights) was shortened substantially (Fig. 7). The mechanism for this effect apparently involves (i) increased heating of the soil during the day under the mulch, especially on sunny days (i.e., a "solarization" effect); (ii) reduced soil heat loss due to reduced soil evaporation; and (iii) increased thermal radiation from the warmer soil at night, which warms leaves and air enough to reduce dew duration. Thus, increased heat storage by a body with sufficient heat storage capacity can reduce dew duration (5).

Following the success of using this nonchemical measure in suppressing the two destructive pathogens Phytophthora infestans and Pseudoperonospora cubensis, mulching was examined experimentally by us and others in Israel in other pathosystems. Replicated experiments showed that polyethylene mulch had an influence on gray mold (caused by $B$. cinerea) in tomato, sweet basil, and pepper (unpublished); on tomato leaf mold (caused by Cladosporium fulvum); and on cucumber damping off (caused by Pythium spp.). In lisianthus, polyethylene mulch suppressed gray mold significantly compared with the common practice of growing lisianthus in bare soil. However, the effect was attributed not only to changes in dew deposition but also to the physical barrier that was formed between the lower, soil-touching leaves and the wet soil, which affects conditions for development of infection along these leaves toward the stem base (26). Mulching had no effect on powdery mildew in sweet pepper and cucumber (caused by Leveillula taurica and Sphaerotheca fusca, respectively) and on Alternaria in eggplants (caused by A. solani). On several occasions, mulching had noticeable effects on the host plants: cucumber and basil grew faster at early stages of the season leading to earlier yields of cucumber and higher yields of basil. Furthermore, chilling damage in basil leaves (caused by low night temperatures) was significantly reduced in plants growing in polyethylene-mulched soil (unpublished). These effects may be attributed to the heating of the soil in the mulched structures.

Although the physical mechanisms by which covering the soil with polyethylene mulch reduced leaf wetness duration are not fully understood, this new technology has already been adopted by Israeli organic and other tomato growers, based on early reports of our research. Thus, the majority of tomato greenhouses in Israel currently apply polyethylene mulches. Furthermore, mulching is increasingly practiced in other greenhouse crops, such as cucumber, pepper, sweet basil, eggplant, and ornamentals. There, growers have reported other benefits, including prevention of

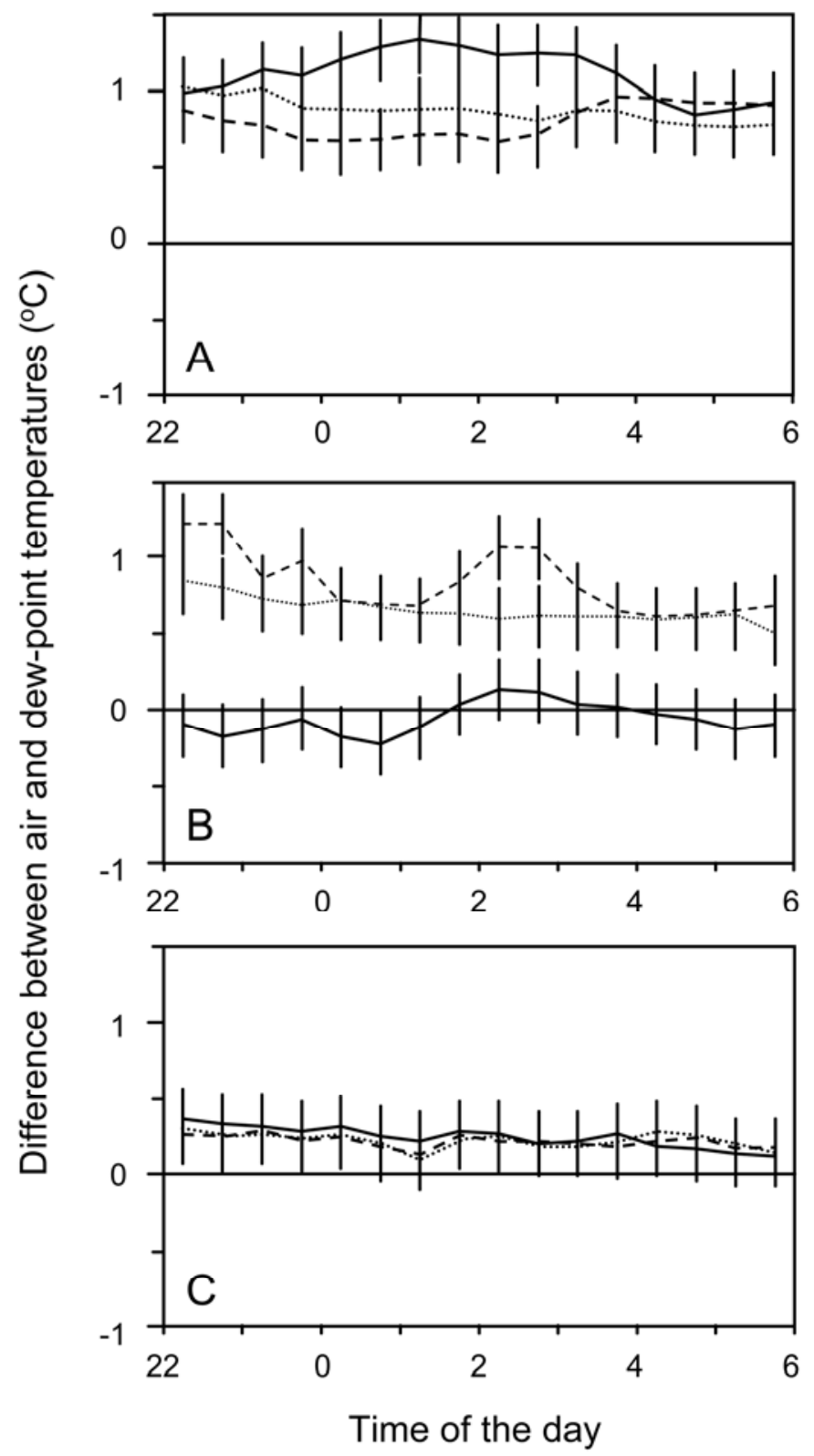

Fig. 6. Effect of the type of the polyethylene mulch on dew formation for three nights in the spring 2006 experiment. A, Dewless night (April 12 to 13); $\mathbf{B}$, dew formed only in the nonmulched tunnels (April 19 to 20); C, dew formed in all tunnels (April 6 to 7). Solid line, tunnels with nonmulched soil; dashed line, bicolor aluminized polyethylene mulch; dotted lines, clear polyethylene mulch. Vertical bars represent the sensors' measurement error $\left( \pm 0.2^{\circ} \mathrm{C}\right)$. 

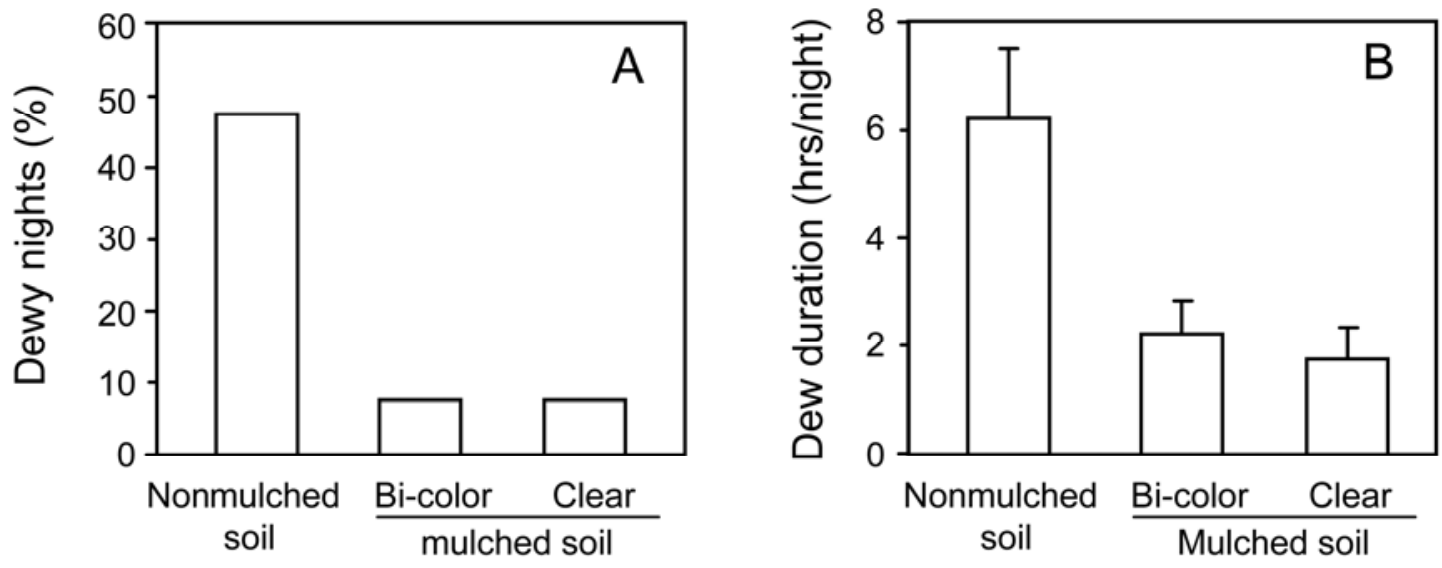

Fig. 7. Effects of the type of polyethylene mulch on dew formation in the spring 2006 experiment. A, Proportion of dewy nights and B, dew duration (h) in the dewy nights. Vertical bars represent the standard error.

weed infestation (when using bicolor polyethylene), saving up to $30 \%$ of irrigation water, and suppression of numerous insect pests. These observations should be studied and confirmed in detailed experiments. Polyethylene mulch may also harm plants if applied indiscriminately. Planting tomato and pepper seedlings in polyethylene-mulched soil in midsummer resulted in seedling mortality, presumably from high soil temperatures.

Although the potential benefits of this practice seem to exceed its negative aspects, a better understanding of the physical mechanisms leading to the biological effects should be developed. This knowledge will enable its implementation at times when it can improve crop production and disease management.

\section{ACKNOWLEDGMENTS}

This research was supported in part by grants no. 132-1109 and 1321203 from Chief Scientist of the Israeli Ministry of Agriculture. We thank E. Matan, M. Tregerman, H. Yehezkel, L. Ganot, and D. Shmuel from the Be'sor experimental farm of R\&D South for their technical assistance. Contribution no. 507/09 from the Institute of Plant Protection, ARO, the Volcani Center, Bet Dagan, Israel.

\section{LITERATURE CITED}

1. Antignus, Y. 2007. The management of tomato yellow leaf curl virus in greenhouses and the open field, a strategy of manipulation. Pages 263-278 in: Tomato Yellow Leaf Curl Virus Disease. H. Czosnek, ed. SpringerVerlag, New York.

2. Baille, A., Lopez, J. C., Bonachela, S., Gonzalez-Real, M. M., and Montero, J. I. 2006. Night energy balance in a heated low-cost plastic greenhouse. Agric. For. Meteorol. 137:107-118.

3. Becktell, M. C., Daughtrey, M. L., and Fry, W. W. 2005. Temperature and leaf wetness requirements for pathogen establishment, incubation period, and sporulation of Phytophthora infestans on Petunia $\times$ hybrida. Plant Dis. 89:975-979.

4. Berg, A. 1926. Tomato Late Blight and Its Relation to Late Blight of Potato. West Virginia University Agricultural Experimental Station, Morgantown.

5. Campbell, G. S., and Norman, J. M. 1998. An Introduction to Environmental Biophysics. Springer-Verlag, New York.

6. Cohen, S., Ziv, G., Elad, Y., Grava, A., and Shtienberg, D. 2006. Influence of polyethylene mulch on night microclimate, dew point and Phytophthora infestans infection in non heated tomato greenhouses in southern Israel. Acta Hortic. No. 718:277-282.

7. Cohen, Y. 1977. The combined effects of temperature, leaf wetness, and inoculum concentration on infection of cucumbers with Pseudoperonospora cubensis. Can. J. Bot. 55:1478-1487.

8. Cohen, Y. 1981. Downy mildew of cucurbits. Pages 341-354 in: The Downy Mildews. D. M. Spenser, ed. Academic Press, London.

9. Crosier, W. F. 1933. Studies in the Biology of Phytophthora infestans (Mont.) de Bary. Cornell University, Ithaca, NY.

10. Duncan, J. M. 2003. Breeding to tackle blight without copper on PM. Nature 425:15

11. Eijsackers, H., Beneke, P., Maboeta, M., Louw, J. P. E., and Reniecke, A. J. 2005. The implications of copper fungicides usage in vineyards for earthworm activity and resulting sustainable soil quality. Ecotoxicol. Environ. Saf. 62:99-111.

12. Elad, Y. 2000. Changes in disease epidemics on greenhouse grown crops. Acta Hortic. No. 534:213-220.

13. Elad, Y., and Shtienberg, D. 1995. Botrytis cinerea in greenhouse vegetables: Chemical, cultural, physiological and biological controls and their integration. Integr. Pest Manage. Rev. 1:15-29.

14. Fry, W. E., Thurston, H. D., and Stevenson, W. R. 2001. Late blight. In: Compendium of Potato Diseases. W. R. Stevenson, R. Loria, G. D. Franc, and D. P. Weingartner, eds. American Phytopathological Society Press. St. Paul, MN.

15. Ghorbani, R., Wilcockson, S. J., Giotis, C., and Leifert, C. 2004. Potato late blight management in organic agriculture. Out. Pest Manage. 15:176-280.

16. Grundy, C., and Bond, B. 2007. Use of non-living mulches for weed control . Pages 135-154 in: Non Chemical Weed Management Principles, Concepts and Technology. M. K. Upadhyaya and R. E. Blackshaw, eds. CABI, Wallingford, UK.

17. Harrison, J. R. 1992. Effects of the aerial environment on late blight of potato foliage-a review. Plant Pathol. 41:384-416.

18. Jolliet, O. 1999. The greenhouse water cycle. Pages 303-326 In: The Greenhouse Ecosystem. G. Stanhill and H. Z. Enoch, eds. Elsevier, The Netherlands.

19. Katan, J., and DeVay, J. E. 1991. Soil Solarization. CRC Press, Boca Raton, FL

20. Kosman, E., and Cohen, Y. 1996. Procedures for calculating the differentiating synergism and antagonism in action of fungicide mixtures. Phytopathology 86:1263-1272.

21. Levy, Y., Benderly, M., Cohen, Y., Gisi, U., and Bassand, D. 1986. The joint action of fungicides in mixtures; comparison of two methods for synergy calculation. Bull. EPPO 16:651-657.

22. Mills, D. J., Coffman, C. B., Teasdale, J. R., Everts, K. L., and Anderson, J. D. 2002. Factors associated with foliar disease of staked fresh market tomatoes grown under differing bed strategies. Plant Dis. 86:356-361.

23. Mizubuti, E. S. G., and Fry, W. E. 2006. Potato late blight. Pages 445-171 in: The Epidemiology of Plant Diseases, 2nd ed. B.M. Cooke, D. F. Jones, and B. Kaye, eds. Springer-Verlag, Dordrecht, The Netherlands.

24. Palti, J., and Cohen, Y. 1980. Downy mildew of cucurbits (Pseudoperonospora cubensis): The fungus and its hosts, distribution, epidemiology and control. Phytoparasitica 8:109-147.

25. Ristaino, J. B., and Thomas, W. 1997. Agriculture, methyl bromide, and the ozone hole: Can we fill the gaps? Plant Dis. 81:964-977.

26. Shpialter, L., Rav David, D., Dori, I., Yermiahu, U., Pivonia, S., Levite, R., and Elad, Y. 2009. Cultural methods and environmental conditions affecting gray mold and its management in lisianthus. Phytopathology 99:557-570.

27. Singh, R., Sharma, R. R., and Goyal, R. K. 2007. Interactive effects of planting time and mulching on 'Chandler' strawberry (Fragaria $\times$ ananassa Duch.). Sci. Hortic. 111:344-351.

28. Solerino, T., Suárez-Rey, E. M., Morales, M. I., Romero, M., Hernández, J., Montero, J. I., Antón, A., and Castilla, N. 2009. Solar radiation transmission in Mediterranean plastic greenhouses. Acta Hortic. No. 807:73-78.

29. Stevenson, W. R. 1991. Late blight. In: Compendium of Tomato Diseases. J. B. Jones, J. P. Jones, R. E. Stall, and T. A. Zitter, eds. American Phytopathological Society, St. Paul, MN.

30. Tarara, M. J. 2000. Microclimate modification with plastic mulch. Hortic. Sci. 35:169-180.

31. Thomas, C. E. 1977. Influence of dew on downy mildew of cantaloupe in south Texas. Phytopathology 67:1368-1369. 